JURNAL RISET MAHASISWA AKUNTANSI

http://ejournal.unikama.ac.id/index.php/jrma

JRMA, Volume 6, No 2, Oktober 2018

\title{
PENGARUH KOMPETENSI DAN INDEPENDENSI AUDITOR TERHADAP KUALITAS AUDIT PADA KAP DI WILAYAH MALANG RAYA
}

\author{
Alfonsa Meltisiana Gunur \\ e-mail : ochaagunur@gmail.com \\ Sulistyo \\ Supami Wahyu S. \\ Program Studi Akuntansi Fakultas Ekonomika Dan Bisnis Universitas Kanjuruhan \\ Malang
}

\begin{abstract}
ABSTRAK
Perkembangan era globalisasi yang semakin maju mengarah pada persaingan yang ketat di dunia bisnis. Hal ini terlihat di dunia bisnis untuk selalu menjaga keakuratan dan akuntabilitas laporan keuangan melalui kegiatan audit. Dalam mengaudit laporan keuangan diperlukan auditor yang kompeten dan independen untuk menghasilkan kualitas audit. Namun, masih banyak kasus yang menghantam akuntan publik sehingga publik meragukan kompetensi dan independensi auditor. Penelitian ini dilakukan dengan menyebarkan kuesioner kepada auditor di wilayah KAP Malang Raya. Metode yang digunakan adalah analisis regresi linier berganda. Berdasarkan penelitian, nilai kompetensi dan independensi sig 0,037 lebih kecil dari 0,05, nilai kompetensi sig 0,019 lebih kecil dari 0,05, independensi nilai sig. 0,009 lebih kecil dari 0,05. Dari hasil penelitian ini, 1) kompetensi dan independensi secara simultan berpengaruh terhadap kualitas audit, 2) Kompetensi berpengaruh parsial terhadap kualitas audit dan 3) Independensi berpengaruh parsial terhadap kualitas audit.
\end{abstract}

Kata Kunci: Kompetensi, independensi, Kualitas Audit

\begin{abstract}
The development of an increasingly advanced era of globalization leads to intense competition in the business world. This is seen in the business world to always maintain the accuracy and accountability of financial statements through auditing activities. In auditing financial statements required a competent and independent auditors in order to produce audit quality. However, there are still many cases that hit public accountants so that the public doubts the competence and independence of auditors. This research was conducted by distributing questionnaires to auditors in KAP Malang Raya area. The method used is multiple linear regression analysis. Based on the research, the competence and the independence value of sig 0,037 are smaller than 0,05, the competence value of sig 0,019 is smaller than 0,05, independence of sig value. 0.009 is smaller than 0,05 From the results of this study, 1) competence and independence has simultaneously effect on audit quality, 2) Competence has partial effect on audit quality and 3) Independence has partial effect affect on audit quality.
\end{abstract}

Keywords: competence, Independence, Audit Quality 


\section{PENDAHULUAN}

Persaingan yang ketat pada dunia ekonomi dan bisnis pada era globalisasi yang semakin modern membuat dunia akuntansi dalam bidang auditing pun ikut terpengaruh. Untuk menjaga mutu laporan keuangannya maka diperlukannya kegiatan pengauditan yang dilakukan oleh auditor independen (auditor eksternal) yang berkompeten dan berindependen. Auditor haruslah orang yang benar-benar memahami semua aturan kode etik, standar, dan prosedur audit yang telah ditetapkan.

Profesi akuntan publik (auditor) merupakan profesi kepercayaan tidak hanya bagi pihak internal (manajemen) dan pihak eksternal (investor, kreditor, kantor pajak, dan lain-lain) namun juga bagi pihak lain (masyarakat) yang tidak terlibat secara langsung. Disini jasa auditor sangat diperlukan sebagai penjamin dari relevan dan keandalan laporan keuangannya berdasarkan aturan FASB (Financial Accounting Standards Board). Selain itu jasa seorang auditor juga untuk mengetahui wajar dan tidaknya laporan tersebut serta mengetahui adanya praktek kecurangan yang dilakukan oleh karyawan atau orang yang terlibat dalam organisasi (Futri \& Juliarasa, 2014).

Kompetensi merupakan hal yang paling penting yang harus dimiliki oleh seorang yang berprofesi sebagai akuntan publik. Kompetensi adalah keahlian profesional seorang auditor yang didapat melalui pendidikan formal, ujian profesional, maupun keikutsertaan dalam pelatihan, seminar, simposium dan lainlain (Ningsih \& Yaniartha, 2013). Namun sesuai dengan tanggung jawabnya untuk menaikkan tingkat keandalan laporan keuangan suatu perusahaan maka akuntan publik tidak hanya perlu memiliki kompetensi atau keahlian saja tetapi juga harus independen dalam pengauditan. Sikap kompetensi dan independensi seorang auditor yang merupakan bagian dari indikator kualitas audit berperan penting dalam menghasilkan laporan audit yang berkualitas yang bisa dipercaya. Menurut (Rosnidah, Rawi, \& Kamarudin, 2010) kualitas audit adalah pelaksanaan audit yang dilakukan sesuai dengan standar sehingga mampu mengungkapkan dan melaporkan apabila terjadi pelanggaran yang dilakukan klien.

Guna menunjang profesionalisme sebagai akuntan publik maka auditor dalam melaksanakan tugas audit harus berpedoman pada standar audit yang ditetapkan oleh Institut Akuntan Publik Indonesia (2011:150.1-150.2), yang terdiri dari standar umum, standar khusus, dan standar pelaporan.

Namun, kenyataannya, sampai hari ini banyak sekali kasus audit yang terjadi yang dilanggar oleh seorang auditor. Terdapat beragam fenomena dalam praktik audit, seperti sebuah 'ujian atas keabsahan sebuah teori'. Contoh kasusnya untuk kompetensi auditor yaitu Skandal Fraud Akuntansi Menerpa British Telecom dan $\mathrm{PwC}$, kasus pergantian auditor Inovisi Infracom Tbk (INVS) karena laporan keuangan yang bermasalah. Contoh kasus independensi auditor yaitu Kasus Suap Auditor BPK oleh pejabat Kemendes dan kasus Auditor BPK Terima Moge HarleyDavidson Terkait Audit Jasa Marga. Contoh kasus kualitas audit yaitu kasus KPK memeriksa Kualitas Audit Sumber Waras dan juga kasus Ketika Afiliasi Ernst \& Young Salah Audit Keuangan Indosat.

Berangkat dari beberapa kasus tersebut maka peneliti pun tertarik untuk membahas mengenai pengaruh kompetensi dan independensi auditor terhadap kualitas audit dengan mengambil studi kasus auditor KAP di Malang. Berdasarkan latar belakang di atas permasalahan yang dijadikan objek penelitian adalah 1) apakah kompetensi dan independensi berpengaruh terhadap kualitas audit di Wilayah Malang Raya? 2) apakah kompetensi berpengaruh terhadap kualitas audit 
di Wilayah Malang Raya? 3) apakah independensi berpengaruh terhadap kualitas audit di Wilayah Malang Raya?

\section{KAJIAN PUSTAKA}

\section{KUALITAS AUDIT}

Berdasarkan Standar Professional Akuntan Publik (SPAP) audit yang dilaksanakan oleh seorang auditor dapat dikatakan berkualitas jika memenuhi ketentuan atau standar yang berlaku umum (Generally Accepted Auditing standards) dan standar pengendalian mutu agar dijadikan acuan auditor dalam memenuhi tanggung jawab profesionalnya dalam audit laporan keuangan.

Menurut (Singgih, Muliani, \& Bawono, 2010) agar laporan keuangan bisa berkualitas maka auditor kompeten harus mampu menemukan adanya pelanggaran dan auditor independen adalah auditor yang mau mengungkapkan pelanggaran tersebut. Kualitas audit ditentukan oleh 2 hal yaitu kompetensi (keahlian) dan independensi. Kedua hal tersebut berpengaruh langsung terhadap kualitas audit.

Terdapat beberapa indikator yang digunakan untuk mengukur kualitas audit laporan keuangan menurut (Wooten, 2003) dalam (Indah, 2010) yaitu sebagai berikut:

1. Deteksi Salah Saji

2. Kesesuaian dengan Standar Profesional Akuntan Publik.

3. Kepatuhan Terhadap Standar Operasional Perusahaan (SOP)

4. Risiko Audit.

5. Prinsip Kehati-hatian.

6. Proses Pengendalian atas Pekerjaan oleh Supervisor.

7. Perhatian yang Diberikan oleh Manajer atau Partner.

\section{KOMPETENSI}

Seorang auditor memiliki peran sebagai pengontrol dan penjaga kepentingan publik yang terkait dengan bidang keuangan. Dalam melaksanakan peran audit, mereka bertanggung jawab untuk merencanakan dan melaksanakan audit guna memperoleh keyakinan yang memadai apakah laporan kuangan bebas dari salah saji material, guna mendukung peran yang cukup mulia itu, seorang auditor harus didukung dengan kompetensi yang memadai akan teknik-teknik audit serta kompetensi lain yang mendukung. Menurut (Arens, Randal, \& Beasley, 2012) seorang auditor yang kompeten harus memiliki kualifikasi untuk memahami kriteria yang digunakan dan harus kompeten untuk mengetahui jenis serta jumlah bukti yang akan dikumpulkan guna mencapai kesimpulan yang tepat setelah memeriksa bukti.

Kualifikasi kompetensi seorang auditor yang dijadikan indikator dalam penelitian ini mencakup dalam dua hal menurut (Indah, 2010) yaitu:

1. Pengetahuan.

2. Pengalaman.

\section{INDEPENDENSI}

Dalam Seksi 290 Kode Etik Profesional Akuntan Publik menyebutkan bahwa independen bagi seorang akuntan publik artinya tidak mudah dipengaruhi karena akuntan publik melaksanakan pekerjaannya untuk kepentingan umum. Dengan demikian auditor tidak dibenarkan memihak kepada kepentingan siapapun, sebab bagaimanapun sempurnanya keahlian teknis yang auditor miliki, auditor akan 
kehilangan sikap tidak memihak, yang justru sangat penting untuk mempertahankan kebebasan pendapatnya. Menurut (Mulyadi, 2010) independensi adalah sikap mental yang bebas dari pengaruh, tidak dikendalikan oleh pihak lain, dan tidak tergantung pada orang lain atau jujur dalam mempertimbangkan fakta dan adanya pertimbangan objektif, tidak memihak dalam diri auditor dalam merumuskan dan menyatakan pendapat. Dalam (seksi 290 Kode Etik Profesional Akuntan Publik ISA) mengenai sikap independensi seorang auditor ada dua yaitu: Independensi dalam pemikiran dan independensi dalam penampilan

Terdapat beberapa indikator untuk melakukan pengukuran independensi berdasarkan penelitian yang dilakukan oleh (Indah, 2010) yaitu:

1. Lama Hubungan dengan Klien (Audit Tenure).

2. Tekanan dari Klien.

3. Telaah dari rekan auditor (peer review)

4. Jasa Non Audit

\section{TINJAUAN EMPIRIK}

Beberapa penelitian terdahulu mengenai kompetensi dan independensi yaitu penelitian yang dilakukan oleh Amalia D. Rosalina tahun 2014 dengan judul Pengaruh Komptensi dan Independensi Auditor terhadap Kualitas Audit (pada KAP Wilayah Bandung) menyatakan bahwa kompetensi dan independensi secara simultan dan parsial berpengaruh terhadap Kualitas Audit. Penelitian yang dilakukan oleh Lauw Tjun Tjun,dkk Tahun 2012 dengan judul pengaruh kompetensi dan independensi auditor terhadap kualitas audit menyatakan bahwa kompetensi berpengaruh terhadap kualitas audit, sedangkan independensi tidak berpengaruh terhadap kualitas audit. kompetensi dan independensi berpengaruh terhadap kualitas audit. Berdasarkan penelitian terdahulu maka dapat disimpulkan bahwa kompetensi, dan independensi berpengaruh terhadap kualitas audit.

\section{KERANGKA PEMIKIRAN}

Menurut (Sugiyono, 2010) kerangka berfikir merupakan model konseptual tentang bagaimana teori berhubungan dengan berbagai faktor yang telah diidentifikasi sebagai masalah yang penting. Kerangka berfikir yang baik akan menjelaskan secara teoritis pertautan antara variabel yang akan diteliti jadi secara teoritis perlu dijelaskan hubungan antar variabel independen terhadap variabel dependen. Oleh karena itu, pada setiap penyusunan paradigma penelitian harus didasarkan pada kerangka berfikir. Untuk merumuskan kerangka pemikiran auditing maka salah satu yang perlu dirumuskan adalah pernyataan yang kebenarannya tidak perlu ditanyakan lagi yang dianggap sebagai suatu persyaratan untuk membangun suatu kerangka teori dimana disiplin itu berkiprah. Menurut (Fadli, 2013) mengemukakan bahwa postulat adalah merupakan syarat penting dalam pengembangan disiplin yang kebenarnnya tidak perlu diperiksa lagi, sebagai dasar dalam pengambilan kesimpulan, sebagai dasar dalam membangun struktur teori dan juga bisa dimodifikasi sesuai dengan perkembangan ilmu pengetahuan. Berdasarkan defenisis tersebut maka (Fadli, 2013) mengemukakan tentang 8 postulat audit yaitu sebagai berikut:

1. Laporan dan data keuangan harus bisa diperiksa

2. Tidak ada konflik kepentingan antara auditor dan manajemen perusahaan yang lagi diperiksa.

3. Laporan dan informasi keuangan diserahkan untuk diperiksa bebas 
dari kolusi dan ketidakteraturan lainnya.

4. System internal control yang memuaskan dapat mengeliminasi kemungkinan ketidakteraturan dalam laporan keuangan.

5. Konsistensi laporan keuangan sesuai standar yang diterima umum sehingga laporan keuangan disajikan secara wajar.

6. Dalam hal bukti tidak jelas atau bertentangan, maka apa yang selama ini dianggap benar sekarang dan dimasa yang akan datang.

7. Pemeriksaan yang dilakukan untuk menyampaikan pendapat yang independen, auditor harus bertindak selaku auditor.

8. Status profesional dari seorang independen auditor menekankan pada tanggung jawab profesional.

Berdasarkan sintesa yang telah ditarik dalam masing-masing variabel independen dan variabel dependen dan tinjauan penelitian terdahulu di atas maka peneliti menggambarkan suatu kerangka pemikiran untuk menganalisis apakah terdapat pengaruh Sikap Kompetensi dan Indpendensi Auditor terhadap Kualitas Audit sebagai berikut:

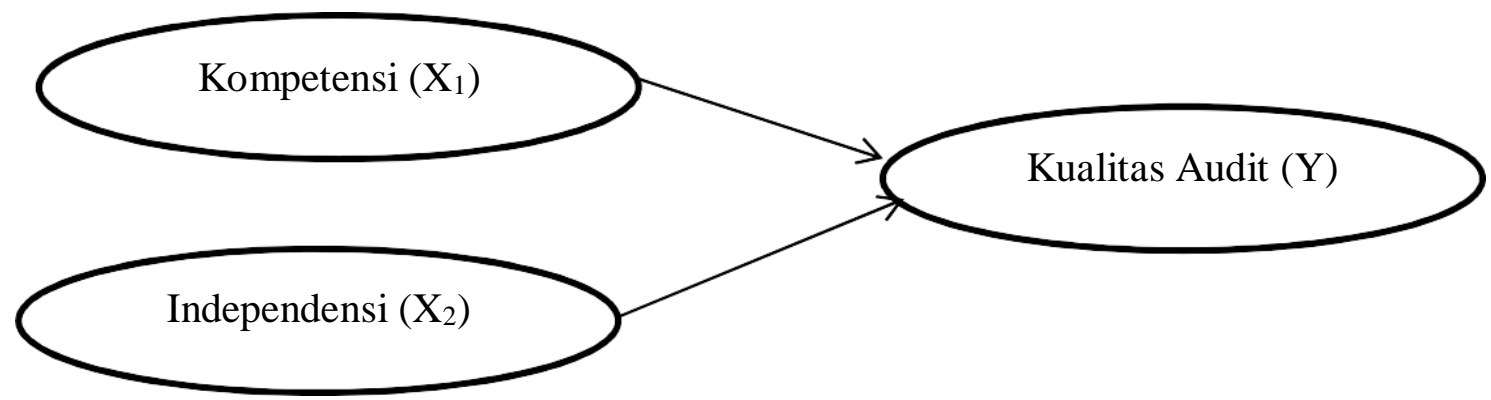

\section{HIPOTESIS}

Berdasarkan telaah teoritis, hasil-hasil penelitian terdahulu, serta kerangka pemikiran teoritis tentang pengaruh independensi, dan kompetensi, terhadap kualitas hasil audit, maka dapat dikembangkan hipotesis dengan penjelasan sebagai berikut:

1. $\mathrm{H}_{1}$ : Kompetensi dan Independensi Auditor Berpengaruh Terhadap Kualitas Audit

2. $\mathrm{H}_{2}$ : Kompetensi Auditor Berpengaruh Terhadap Kualitas Audit.

3. $\mathrm{H}_{3}$ : Independensi Auditor Berpengaruh Terhadap Kualitas Audit

\section{METODE PENELITIAN}

POPULASI DAN SAMPEL

Populasi penelitian ini adalah seluruh auditor yang bekerja pada $12 \mathrm{KAP}$ di wilayah Malang Raya yang terdaftar pada IAPI 2017. Teknik pengambilan sampel menggunakan Simple Random Sampling.

VARIABEL PENELITIAN

Terdapat dua golongan variabel dalam penelitian ini yaitu variabel independen terdiri dari kompetensi $\left(X_{1}\right)$. independensi sebagai $\left(X_{2}\right)$. Variabel dependennya yaitu kualitas audit $(\mathrm{Y})$

TEKNIK PENGUMPULAN DATA

Teknik pengumpulan data dalam penelitian ini adalah dengan menggunakan 
(kuesioner). Pengukuran variabel independen dan dependen menggunakan skala likert. Dengan skala likert, maka variabel yang akan diukur bisa secara mudah dijabarkan menjadi indikator variabel. Skala likert (Sugiyono, 2010) didesain untuk menelaah seberapa kuat subjek setuju atau tidak setuju dengan pernyataan pada skala lima titik yang ditunjukkan dalam table sebagai berikut:

Penilaian Skor pernyataan

\begin{tabular}{|l|c|}
\hline Jawaban & Penilaian(Skor) \\
\hline Sangat Tidak Setuju (STS) & 1 \\
Tidak Setuju (S) & 2 \\
Netral (N) & 3 \\
Setuju (S) & 4 \\
Sangat Setuju (SS) & 5 \\
Sumber : (Sugiyono, 2010) & \\
\hline
\end{tabular}

\section{DEFENISI OPERASIONAL VARIABEL}

1. Variabel independen

a Kompetensi. kompetensi adalah kualifikasi yang dimiliki oleh seorang auditor yang diperoleh melalui pendidikan, pengalaman, pengetahuan, dan pelatihan sehingga mampu menerapkan keahliannya pada saat melakukan kegiatan audit secara profesional.. Indikator yang digunakan yaitu pengetahuan dan pengalaman

b. Independensi. independensi adalah sikap mental seorang auditor yang tidak mudah dipengaruhi dengan tidak memihak terhadap siapapun. Dari pengertian tersebut ada empat indikator yang akan penulis teliti yaitu lama hubungan dengan klien, tekanan dari klien. telaah dari rekan auditor, pemberian jasa non audit.

2. Variabel dependen

Variabel dependennya yaitu kualitas audit. Kualitas audit merupakan kemampuan seorang auditor menemukan dan melaporkan adanya pelanggaran oleh klien yang tidak sesuai dengan standar atau aturan yang berlaku. Selain itu kualitas audit dibuat untuk menjamin bahwa auditor tidak menemukan adanya kesalahan dalam laporan kliennya. Dari pengertian tersebut ada tiga indikator yang akan penulis teliti yaitu deteksi salah saji, kesesuaian dengan SPAP, risiko audit.

\section{METODE PENGUJIAN DATA}

Uji kualitas data menggunakan uji validitas dan uji reliabilitas.. Uji asumsi klasik menggunakan uji normalitas, multikoloniaritas, dan uji heterokedastisitas. Analisis data menggunakan analisis regresi linear berganda. Pengujian hipotesis menggunakan uji $\mathrm{R}^{2}$ uji F dan uji t.

\section{HASIL PENELITIAN DAN PEMBAHASAN}

1. Hasil uji kualitas data

a. Uji validitas

\begin{tabular}{|l|l|l|l|}
\hline Korelasi & Hasil & Kriteria alpa 5\% & Simpulan \\
\hline$X_{1.1}-X_{1}$ total & .000 & $<0,05$ & Valid \\
\hline$X_{1.2}-X_{1}$ total & .001 & $<0,05$ & Valid \\
\hline
\end{tabular}


Alfonsa Meltisiana Gunur, Pengaruh Kompetensi Dan Independensi Auditor Terhadap Kualitas Audit Pada Kap Di Wilayah Malang Raya

\begin{tabular}{|c|c|c|c|}
\hline$X_{1.3}-X_{1}$ total & .000 & $<0,05$ & Valid \\
\hline $\mathrm{X}_{1.4-} \mathrm{X}_{1}$ total & .000 & $<0,05$ & Valid \\
\hline$X_{1.5}-X_{1}$ total & .000 & $<0,05$ & Valid \\
\hline $\mathrm{X}_{1.6-} \mathrm{X}_{1}$ total & .008 & $<0,05$ & Valid \\
\hline $\mathrm{X}_{1.7}-\mathrm{X}_{1}$ total & .002 & $<0,05$ & Valid \\
\hline $\mathrm{X}_{1.8}-\mathrm{X}_{1}$ total & .007 & $<0,05$ & Valid \\
\hline $\mathrm{X}_{1.9}-\mathrm{X}_{1}$ total & .013 & $<0,05$ & Valid \\
\hline$X_{1.10-} X_{1}$ total & .025 & $<0,05$ & Valid \\
\hline$X_{2,1}-X_{2}$ total & .000 & $<0,05$ & Valid \\
\hline $\mathrm{X}_{2.2-2} \mathrm{X}_{2}$ total & .000 & $<0,05$ & Valid \\
\hline $\mathrm{X}_{2.3-3} \mathrm{X}_{2}$ total & .001 & $<0,05$ & Valid \\
\hline $\mathrm{X}_{2.4-} \mathrm{X}_{2}$ total & .029 & $<0,05$ & Valid \\
\hline $\mathrm{X}_{2.5-\mathrm{-}} \mathrm{X}_{2}$ total & .001 & $<0,05$ & Valid \\
\hline $\mathrm{X}_{2.6-} \mathrm{X}_{2}$ total & .002 & $<0,05$ & Valid \\
\hline $\mathrm{X}_{2.7-} \mathrm{X}_{2}$ total & .004 & $<0,05$ & Valid \\
\hline $\mathrm{X}_{2.8}-\mathrm{X}_{2}$ total & .000 & $<0,05$ & Valid \\
\hline $\mathrm{X}_{2.9-} \mathrm{X}_{2}$ total & .012 & $<0,05$ & Valid \\
\hline $\mathrm{X}_{2.10-} \mathrm{X}_{2}$ total & .000 & $<0,05$ & Valid \\
\hline $\mathrm{X}_{2.11-} \mathrm{X}_{2}$ total & .000 & $<0,05$ & Valid \\
\hline $\mathrm{Y}_{1.1-}$ Ytotal & .002 & $<0,05$ & Valid \\
\hline$Y_{1.2}$-Ytotal & .004 & $<0,05$ & Valid \\
\hline$Y_{1.3}-Y$ total & .001 & $<0,05$ & Valid \\
\hline$Y_{1.4-} Y_{\text {total }}$ & .014 & $<0,05$ & Valid \\
\hline $\mathrm{Y}_{1.5-\mathrm{Y}} \mathrm{Y}$ total & .001 & $<0,05$ & Valid \\
\hline $\mathrm{Y}_{1.6} \mathrm{-} Y$ total & .000 & $<0,05$ & Valid \\
\hline $\mathrm{Y}_{1.7-\mathrm{Y}} \mathrm{Y}$ total & .007 & $<0,05$ & Valid \\
\hline $\mathrm{Y}_{1.8-} \mathrm{Y}$ total & .001 & $<0,05$ & Valid \\
\hline
\end{tabular}

Tabel di atas menunjukkan bahwa tingkat signifikansi korelasi antara skor indikator dengan skor total atas variabelnya menunjukkan lebih kecil dari alpa 5\%. Jadi, data yang terkumpul melalui kuesioner mempunyai validitas yang tinggi.

b. Uji reliabilitas

\begin{tabular}{|l|l|l|l|}
\hline Variabel & Hasil & Kriteria & Simpulan \\
\hline $\mathrm{X}_{1}$ & .766 & $>0,6$ & Reliabel \\
\hline $\mathrm{X}_{2}$ & .773 & $>0,6$ & Reliabel \\
\hline $\mathrm{Y}$ & .723 & $>0,6$ & Reliabel \\
\hline
\end{tabular}

Tabel di atas menunjukkan nilai alpa cronbach setiap variabel menunjukkan lebih besar dari 0,6. Jadi, data yang terkumpul melalui kuesioner mempunyai reliabilitas 

yang tinggi.

2. Hasil uji asumsi klasik.

a. Uji normalitas

One-Sample Kolmogorov-Smirnov Test

\begin{tabular}{|c|c|c|}
\hline & & $\begin{array}{l}\text { Unstandardized } \\
\text { Predicted Value }\end{array}$ \\
\hline \multicolumn{2}{|l|}{$\mathrm{N}$} & \multirow{5}{*}{$\begin{array}{l}60 \\
3.8500000 \\
.11550400 \\
.082 \\
.082 \\
-.044 \\
.0633\end{array}$} \\
\hline Normal Parameters & $\begin{array}{l}\text { Mean } \\
\text { Std. Deviation }\end{array}$ & \\
\hline $\begin{array}{ll}\text { Most } & \text { Extreme } \\
\text { Differences } & \end{array}$ & $\begin{array}{l}\text { Absolute } \\
\text { Positive } \\
\text { Negatif }\end{array}$ & \\
\hline \multicolumn{2}{|l|}{ Kolmogorof-Smirnof Z } & \\
\hline Asymp.Sig. (2-tailed) & & \\
\hline
\end{tabular}

a. Test distribution is Normal.

Tabel di atas menunjukkan bahwa nilai signifikansi Kolmogorof-Smirnov sebesar 0.817 lebih besar dari 0.05 (5\%). Ini berarti bahwa data variabel pengganggu memiliki distribusi normal.

b. Uji multikoloniaritas

\begin{tabular}{|l|l|l|l|}
\hline Variabel Bebas & Hasil & Kriteria & Simpulan \\
\hline $\mathrm{X}_{1}$ & 1.002 & $<10$ & Tidak ada multikolinieritas \\
\hline $\mathrm{X}_{2}$ & 1.002 & $<10$ & Tidak ada multikolinieritas \\
\hline
\end{tabular}

Tabel di atas menunjukkan bahwa nilai VIF (Variance Inflation Factor) setiap variabel bebas lebih kecil dari 10. Ini berarti bahwa tidak ditemukan adanya korelasi antar variabel bebas. 
c. Uji heteroskedastisitas

Scatterplot

Dependent Variable: y1

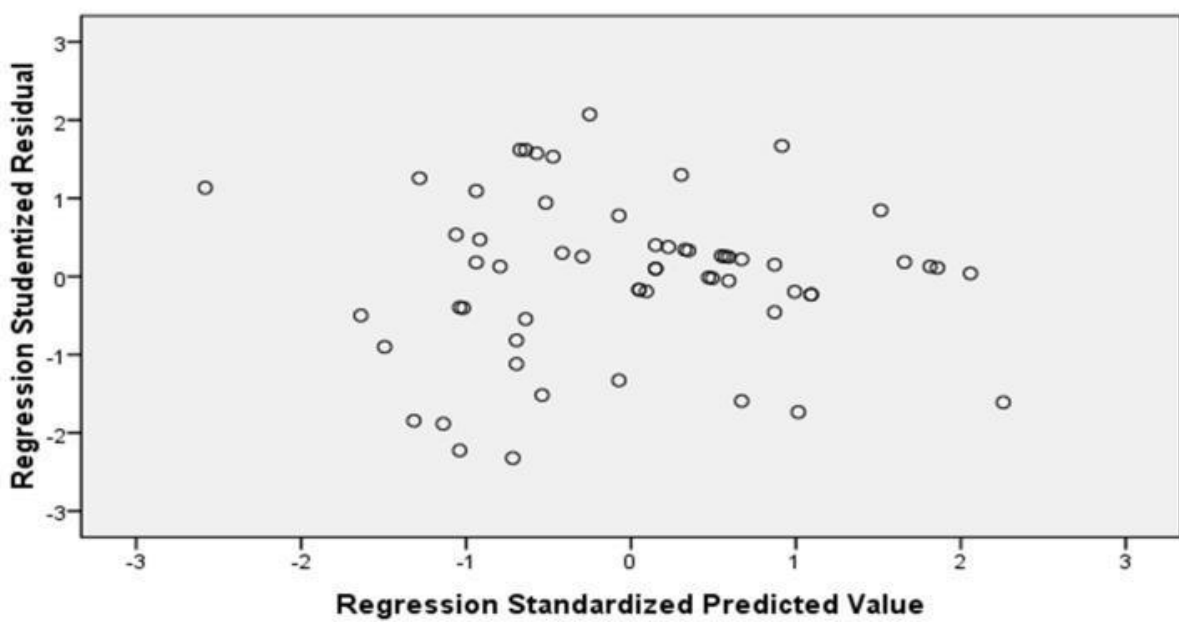

Gambar di atas menunjukkan bahwa gambar scatterplot tidak beraturan atau tidak membentuk suatu pola atau gambar tertentu. Ini berarti bahwa terjadi ketidaksamaan variance dari residual satu pengamatan ke pengamatan yang lain. Grafik plot menunjukkan tidak beraturan dinyatakan tidak terjadi heteroskedastisitas.

3. Analisis regresi linear berganda $Y$

$=2.099+0.372 X_{1}+0.538 X_{2}$

Ringkasan Hasil Analisis Regresi Linier Berganda

\begin{tabular}{|l|l|l|l|}
\hline Variabel & Koefisien regresi & Nilai Sign. & Simpulan \\
\hline$X_{1}$ (Kompetensi) & $\mathbf{0 . 3 7 2}$ & $0.019<0.05$ & Berpengaruh \\
\hline$X_{2}$ (Independensi) & $\mathbf{0 . 5 3 8}$ & $0.009<0.05$ & Berpengaruh \\
\hline Nilai signifikansi uji $\mathrm{F}=0.037$ \\
\hline
\end{tabular}

Berdasarkan tabel di atas dapat diinterprestasikan sebagai berikut:

1. Koefisien regresi variabel kompetensi $\left(\mathrm{X}_{1}\right)$ dengan hasil perhitungan regresi menunjukan bahwa variabel $\left(\mathrm{X}_{1}\right)$ berhubungan dengan kualitas audit $(\mathrm{Y})$, artinya jika indikator variabel independensi ditingkatkan keberadaanya maka variabel kualitas audit $(\mathrm{Y})$ akan mengalami kenaikan dengan asumsi variabel independen lain bernilai tetap atau tidak berubah.

2. Koefisien regresi variabel independensi $\left(X_{2}\right)$ dengan hasil perhitungan regresi menunjukan bahwa variabel $\left(\mathrm{X}_{1}\right)$ berhubungan dengan kualitas audit $(\mathrm{Y})$, artinya jika indikator variabel independensi ditingkatkan keberadaanya maka variabel kualitas audit $(\mathrm{Y})$ akan mengalami kenaikan dengan asumsi variabel independen lain bernilai tetap atau tidak berubah.

3. Nilai R-square sebesar 0,548 menunjukkan bahwa naik turunnya atau perubahan kualitas audit sebesar $54,8 \%$ dipengaruhi oleh variabel 
Alfonsa Meltisiana Gunur, Pengaruh Kompetensi Dan Independensi Auditor Terhadap Kualitas Audit Pada Kap Di Wilayah Malang Raya

kompetensi dan independensi auditor. Sisanya sebesar 45,2\% dipengaruhi oleh variabel lain yang tidak diteliti.

4. Uji Hipotesis

a. Uji F

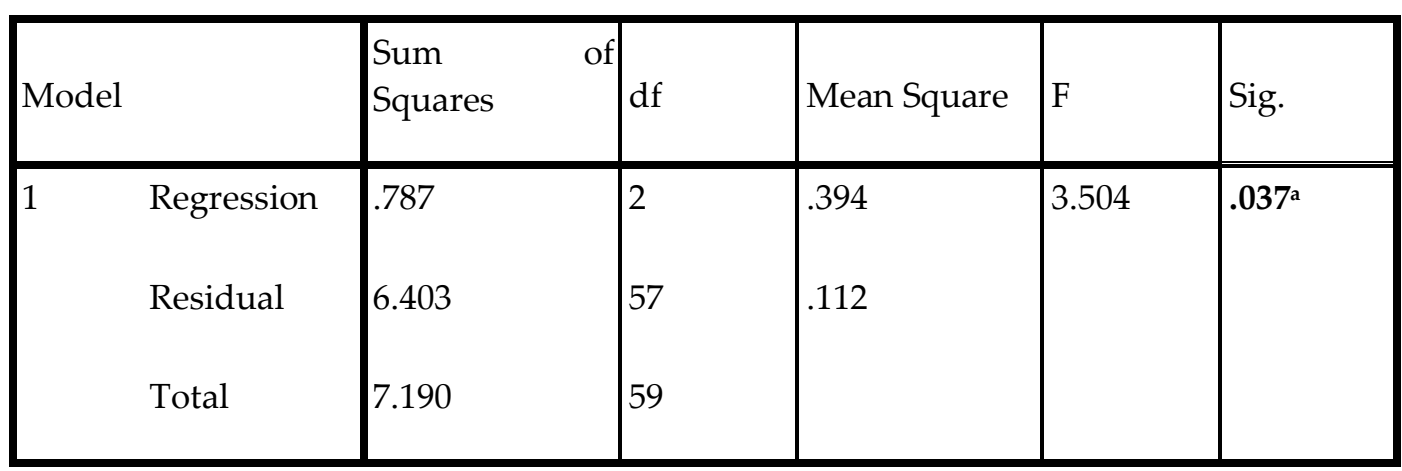

a. Predictors: (Constant), $\mathrm{x} 2, \mathrm{x} 1$

b. Dependent Variable: $y 1$ berikut:

Berdasarkan tabel di atas maka dapat dilakukan pengujian hipotesis sebagai

1. Pengujian Hipotesis $\mathrm{H}_{1}$. Berdasarkan tabel di atas dan diketahui bahwa pengaruh secara bersama-sama variabel independen terhadap variabel dependen dilakukan dengan melihat nilai uji $\mathrm{F}$ sebesar 3.504 dengan signifikan 0,037. Dimana disyaratkan nilai signifikansi F lebih kecil dari 0.05. Jadi, dapat dikemukakan bahwa hipotesis pertama yang menyatakan "terdapat pengaruh secara simultan antara kompetensi dan independensi terhadap kualitas audit", dapat diterima.

b. Uji t

Coefficients ${ }^{a}$

\begin{tabular}{|c|c|c|c|c|c|c|c|c|}
\hline \multirow{2}{*}{\multicolumn{2}{|c|}{ Model }} & \multicolumn{2}{|c|}{$\begin{array}{l}\text { Unstandardized } \\
\text { Coefficients }\end{array}$} & \multirow{2}{*}{$\begin{array}{l}\begin{array}{l}\text { Standardize } \\
\text { d } \\
\text { Coefficients }\end{array} \\
\text { Beta }\end{array}$} & \multirow[b]{2}{*}{$\mathrm{t}$} & \multirow[b]{2}{*}{ Sig. } & \multicolumn{2}{|c|}{$\begin{array}{l}\text { Collinearity } \\
\text { Statistics }\end{array}$} \\
\hline & & B & $\begin{array}{l}\text { sta. } \\
\text { Error }\end{array}$ & & & & Tolerance & VIF \\
\hline \multirow[t]{3}{*}{1} & (Constant) & 2.099 & .678 & & 3.097 & .003 & & \\
\hline & $\mathrm{x} 1$ & .372 & .154 & .301 & 2.407 & .019 & .998 & 1.002 \\
\hline & $x 2$ & .538 & .118 & .123 & 2.981 & .009 & .998 & 1.002 \\
\hline
\end{tabular}

a. Dependent Variable: $Y$

Berdasarkan tabel di atas maka dapat dilakukan pengujian hipotesis sebagai berikut:

1. Pengujian Hipotesis $\mathrm{H}_{2}$. Berdasarkan tabel 4.11 di atas menunjukkan nilai 
sig. 0,019 lebih kecil dari 0,05, artinya variabel independensi berpengaruh terhadap kualitas audit pada $\alpha=0,05$ (tingkat kesalahan 5\%). Jadi, dapat dikemukakan bahwa hipotesis kedua yang menyatakan "terdapat pengaruh secara parsial antara kompetensi auditor terhadap kualitas audit", dapat diterima.

2. Pengujian Hipotesis $\mathrm{H}_{3}$. Berdasarkan tabel 4.11 di atas menunjukkan nilai sig. 0,009 lebih kecil dari 0,05, artinya variabel independensi berpengaruh terhadap kualitas audit pada $\alpha=0,05$ (tingkat kesalahan 5\%). Jadi, dapat dikemukakan bahwa hipotesis ketiga yang menyatakan "terdapat pengaruh secara parsial antara independensi auditor terhadap kualitas audit", dapat diterima.

\section{KESIMPULAN DAN SARAN}

KESIMPULAN

Berdasarkan hasil penelitian yang diperoleh maka dapat diambil kesimpulannya yaitu:

1. Pengujian hipotesis pertama menunjukan bahwa variabel kompetensi dan independensi secara simultan mempunyai pengaruh terhadap kualitas audit.

2. Pengujian hipotesis kedua menunjukan bahwa variabel kompetensi secara parsial mempunyai pengaruh terhadap kualitas audit.

3. Pengujian hipotesis ketiga menunjukan bahwa variabel independensi secara parsial mempunyai pengaruh terhadap kualitas audit.

\section{SARAN}

Berdasarkan hasil penelitian yang telah dilakukan maka diajukan saran, antara lain:

1. KAP dan Auditor

Penelitian mengenai kompetensi, independensi, dan kualitas audit penting bagi Kantor Akuntan Publik dan auditor di wilayah Malang raya agar mereka dapat mengetahui faktor-faktor yang mempengaruhi kualitas audit dan selanjutnya meningkatkannya.

2. Pemakai Jasa Audit

Bagi pemakai jasa audit, penelitian ini penting agar dapat menilai KAP mana yang konsisten dalam menjaga kompetensi, independensi dan kualitas audit yang diberikannya.

3. Universitas Kanjuruhan Malang

Penelitian ini diharapkan bisa menambah dan melengkapi referensi atau sumber bagi Universitas Kanjuruhan Malang.

4. Penulis

Sebagai pembuktian penerapan akan ilmu yang telah didapatkan selama perkuliahan terutama tentang kompetensi, independensi dan kualitas audit. 


\section{DAFTAR PUSTAKA}

Arens, A. A., Randal, J. E., \& Beasley, M. (2012). Auditing and Assurance Service- an Integrated Approach. Prentice Hall.

Fadli. (2013, September). Postulat Auditing. Retrieved Februari 27, 2019, from Jago Akuntansi: http://www.Jagoakuntansi.com

Futri, P. S., \& Juliarasa, G. (2014). Pengaruh Independensi, Profesionalisme, Tingkat Pendidikan, Etika Profesi, Pengalaman, dan Kepuasan Kerja Auditor pada Kualitas Audit Kantor Akuntan Publik di Bali. E-Jurnal Akuntansi Universitas Udayan 7.2, 444-461.

Indah, S. M. (2010). Pengaruh Kompetensi dan Independensi Auditor terhadap Kualitas Audit (Studi Empiris pada KAP di Semarang). Skripsi Universitas Diponegoro.

Mulyadi. (2010). Auditing Buku ke 6 Edisi 1. Jakarta: Salemba Empat.

Ningsih, \& Yaniartha. 2013. Pengaruh Kompetensi, Independensi, Time Budget Pressure terhadap Kualitas Audit. E-Jurnal Akuntansi Universitas Udayana.

Rosalina, A. D. (2014). Pengaruh Kompetensi dan Independensi terhadap Kualitas Audit (pada Kantor Akuntan Publik di Wilayah Bandung). Jurnal Skripsi Widyatama.

Rosnidah, I., Rawi, \& Kamarudin. (2010). Analisis Dampak Motivasi dan Profesionalisme terhadap Kualitas Audit Aparat Inspektorat dalam Pengawasan Keuangan Daerah (Studi Empiris pada Pemerintah Kabupaten Cirebon). Jurnal Akuntansi. Bandung.

Singgih, Muliani, E., \& Bawono, I. R. (2010). Pengaruh Independensi, Pengalaman, Due Professional Care, dan Akuntabilitas Terhadap Kualitas Audit. Simposium Nasional Akuntan XIII Purwekerto.

Sugiyono. (2010). Metode Penelitian Kuantitatif Kualitatif dan RED. Bandung: Alfabeta.

Tjun,L.T.,Marpaung,E. I.,\& Setiawan, S. (2012) Pengaruh Kompetensi dan Independensi Auditor terhadap Kualaitas Audit. Jurnal Akuntansi Vol 4 No.1,33-56 